University of Nebraska - Lincoln

DigitalCommons@University of Nebraska - Lincoln

Pervasiveness of Phytoliths in Prehistoric Southwestern Diet and Implications for Regional and Temporal Trends for Dental Microwear

\author{
Karl J. Reinhard \\ University of Nebraska - Lincoln, kreinhard1@mac.com \\ Dennis R. Danielson \\ US Army Central ID Lab, 310 Worchster Ave., Hickman AFB, HI 96858-5530, USA
}

Follow this and additional works at: https://digitalcommons.unl.edu/natrespapers

Part of the Natural Resources and Conservation Commons

Reinhard, Karl J. and Danielson, Dennis R., "Pervasiveness of Phytoliths in Prehistoric Southwestern Diet and Implications for Regional and Temporal Trends for Dental Microwear" (2005). Papers in Natural Resources. 161.

https://digitalcommons.unl.edu/natrespapers/161

This Article is brought to you for free and open access by the Natural Resources, School of at DigitalCommons@University of Nebraska - Lincoln. It has been accepted for inclusion in Papers in Natural Resources by an authorized administrator of DigitalCommons@University of Nebraska - Lincoln. 


\title{
Pervasiveness of phytoliths in prehistoric southwestern diet and implications for regional and temporal trends for dental microwear
}

\author{
Karl J. Reinhard ${ }^{a, *}$, Dennis R. Danielson ${ }^{b}$ \\ ${ }^{a}$ School of Natural Resource Sciences, 309 Biochemistry Hall, University of Nebraska - Lincoln, Lincoln, NE 68583-0758, USA \\ ${ }^{\mathrm{b}}$ c/o Dr Tom Holland, US Army Central ID Lab, 310 Worchster Ave., Hickman AFB, HI 96858-5530, USA
}

Received 15 October 2004; received in revised form 14 January 2005

\begin{abstract}
Our previous analysis of phytolith content of coprolites showed that calcium oxalate phytoliths from desert food plants caused dental microwear among prehistoric Texas hunter-gatherers. We demonstrated that phytoliths from desert succulents were ubiquitous and abundant in hunter-gatherer coprolites. We found that calcium oxalate phytoliths were harder than human dental enamel. We concluded that phytoliths from desert succulent plants caused dental microwear and hypothesized that such dental microwear would be common in other desert hunter-gatherer and horticultural peoples. Presented here are further analyses of phytoliths from coprolites. Two additional hunter-gatherer sites and three Ancestral Pueblo (Anasazi) horticultural sites are included in this study. Calcium oxalate phytoliths are ubiquitous in coprolites from hunter-gatherer sites in the Mojave Desert and the Colorado Plateau. For the three Ancestral Pueblo sites, calcium oxalate phytoliths from desert succulents (agave family and cactus family) are the most common types of phytoliths encountered. However, silica phytoliths are also present in Ancestral Pueblo coprolites. The data demonstrate that phytoliths from non-cultivated desert plants were a source of dental microwear for the premaize Archaic hunter-gatherer bands and maize-reliant Ancestral Pueblo villages.
\end{abstract}

(c) 2005 Published by Elsevier Ltd.

Keywords: Subsistence; Pathology; Ancestral Pueblo; Archaic; Southwest; Coprolite

\section{Introduction}

The relationship of dietary phytoliths to dental microwear in archaeological populations is increasingly multifarious. The introduction of microwear simulation [10] and computer programs for quantifying microwear [29] provide refined analytical bases for characterizing the taphonomy of microwear. The recovery of phytoliths from the surface of teeth $[12,13]$ and from dental calculus $[11,14,22]$ provide direct evidence of the botanical sources

\footnotetext{
* Corresponding author. Tel.: +1 402472 6858; fax: +1 402472 8390 .

E-mail addresses: kreinhard1@unl.edu (K.J. Reinhard), danielsol@ cilhi.army.mil (D.R. Danielson).
}

of phytoliths that cause microwear. Coprolite analysis provides additional evidence of dietary abrasives $[5,20]$. These approaches, when applied to temporal variation in a single region, provide a basis for characterizing changes in microwear related to diet [24].

We feel that it is important to quantify the amount of phytoliths in prehistoric diets. This provides baseline data that indicate which subsistence strategies placed prehistoric human populations at greater microwear risk. We present analyses of phytoliths from coprolites (ancient feces) as a direct means of assessing how commonly phytoliths were consumed in prehistory.

Analysis of phytoliths from hunter-gatherer coprolites in Texas showed that calcium oxalate crystals were a source of dental wear in that region [5]. We proposed 
that since "phytolith-rich plants were the dietary staples for much of the Archaic period in the desert west of North America, it is very likely that calcium oxalate crystals in other desert regions will be linked to prehistoric dental wear." Also, coprolite research shows that desert succulents continued to be a food source in Ancestral Pueblo (Anasazi) horticultural populations $[9,15,17]$. Therefore, we were interested in assessing whether or not calcium oxalate phytoliths were common in Ancestral Pueblo coprolites. It is the goal of the study presented here to expand our analyses of coprolites to other hunter-gatherer and horticultural groups in the southwest and to assess how pervasive phytolith-caused wear was in prehistoric cultures of diverse subsistence bases. For this study, we started with the hypothesis that hunter-gatherers were more reliant on desert succulents and therefore hunter-gatherer coprolites should contain more phytoliths.

\section{Materials and methods}

To evaluate the presence of phytoliths in southwestern prehistoric diets, we extracted phytoliths from 99 coprolites from five archaeological sites (Fig. 1), thus expanding our previous analysis of 14 coprolites from Texas [5]. Two of the sites were hunter-gatherer sites. One of these, Bighorn Cave, is in the northern Sonoran Desert of Arizona. Another is Dust Devil Cave on the Colorado Plateau of Utah. Bighorn Cave coprolites come from several stratigraphic levels dating between 310 and 3395 yr BP [20]. Dust Devil Cave coprolites were excavated from several distinct stratigraphic levels dating between 6400 and $8800 \mathrm{yr}$ BP [19]. Thus, in addition to the coprolites from a Texas hunter-gatherer site previously published [5], we analyzed huntergatherer coprolites from two different arid regions.

Three sites were Ancestral Pueblo horticultural villages. They date to the Pueblo III Period [18]. These included Salmon Ruin, New Mexico [17], Antelope House, Arizona [17], and Bighorn Sheep Ruin, Utah. All of the Ancestral Pueblo sites are located on the Colorado Plateau. They are, however, in distinct ecological niches. Salmon Ruin is located on the flood plain of the San Juan River. Antelope House is located in the canyon bottom of Canyon de Chelly. The ecological differences and variation in resource exploitation between these two sites has been published previously [18]. Bighorn Sheep Ruin is located in the more arid Grand Gulch of Utah and represents an

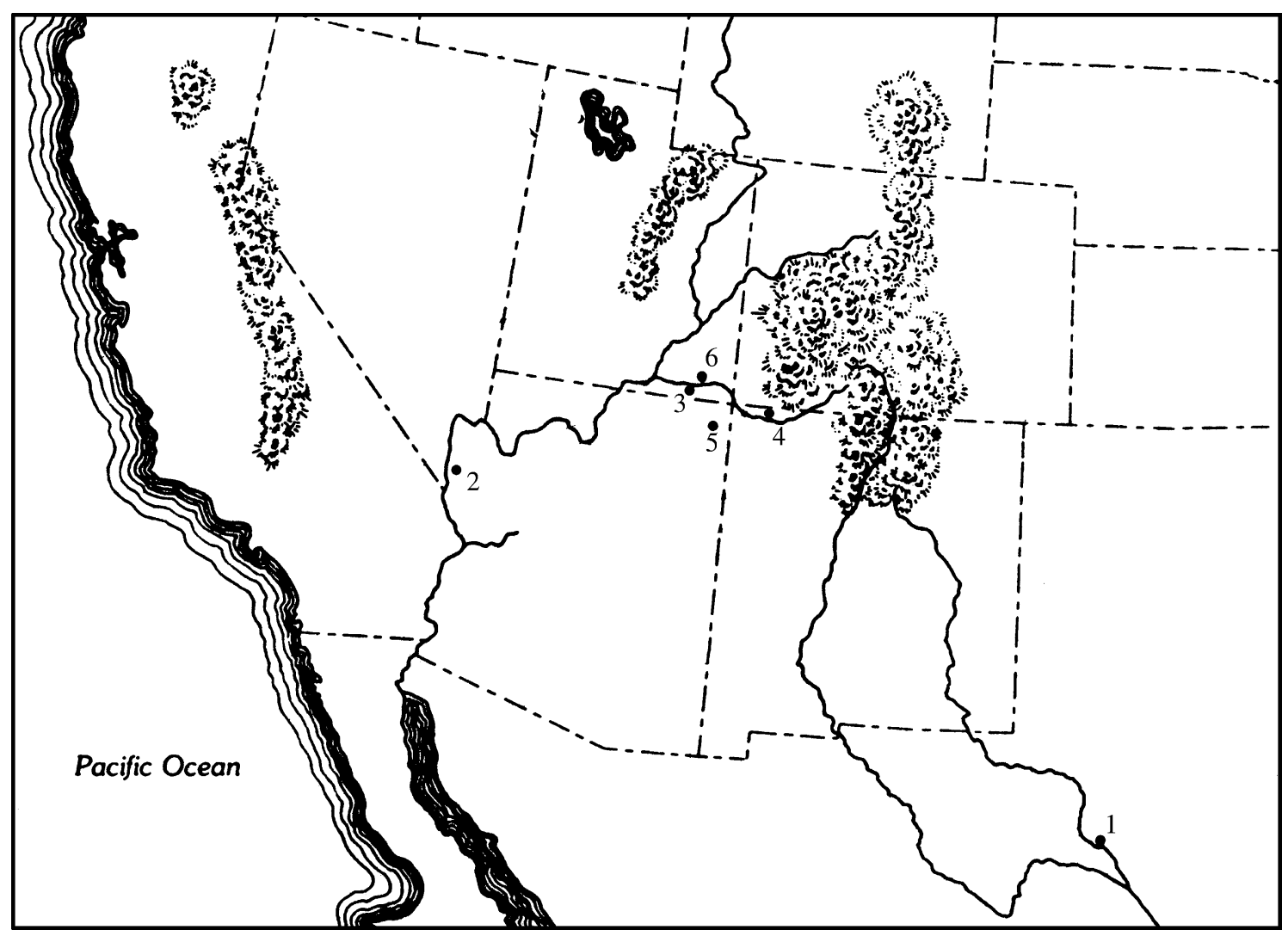

Fig. 1. Study area map showing locations of sites for which coprolites have been analyzed for phytolith content. (1) Hinds Cave, (2) Bighorn Cave, and (3) Dust Devil Cave are hunter-gatherer sites. They are located in the Chihuahuan Desert, the Mojave Desert, and the Colorado Plateau respectively. (4) Salmon Ruin, (5) Antelope House, and (6) Bighorn Sheep Ruin are Ancestral Pueblo sites on the Colorado Plateau. 
Ancestral Pueblo adaptation to more xeric conditions than either Antelope House or Salmon Ruin.

Our methods for extracting phytoliths from plants and coprolites have been detailed elsewhere [5]. Briefly, phytoliths from the coprolites were extracted by dissolving a cleaned, weighed, coprolite fragment in hydrogen peroxide and potassium dichromate. Comparative reference samples were obtained by digesting modern plant samples in hydrogen peroxide and potassium dichromate. The plants samples were collected from ethnobotanically important species in Arizona, Utah, and Texas. The phytolith residues and comparative plant samples used in this study were deposited in the Microfossil Research Facility at the University of Nebraska where they are currently curated. An attempt was made to count 200 phytoliths for each coprolite. Phytoliths were identified by comparison to the reference collections.

\section{Results}

Phytoliths are produced in two chemical forms. Most plants produced silica phytoliths. However, chemical analysis of phytoliths from the cactus family and agave/ yucca family shows that these plants produced calcium oxalate phytoliths [5]. Both types are harder than tooth enamel and dentin [5].

A variety of phytoliths was found in the coprolites (Table 1). For the Archaic sites, the results were similar to those published previously for Texas [5]. Typically, $20 \%$ of the Texas coprolite samples were composed of calcium oxalate phytoliths from Agave and cactus.

The coprolites from Bighorn Cave and Dust Devil Cave were rich in phytoliths. Like the samples from Texas, phytoliths composed up to $20 \%$ of the fecal volume. Phytoliths were abundant in all hunter-gatherer coprolites and 200 phytolith counts were easily achieved. Calcium oxalate phytoliths were especially abundant in the coprolites.

Table 1

Common names for taxa encountered in this analysis

\begin{tabular}{ll}
\hline Agavaceae & $\begin{array}{l}\text { Agave family that includes dietary genera } \\
\text { such as Agave and Yucca } \\
\text { Cactus family. Phytoliths found in this study } \\
\text { Cactaceae }\end{array}$ \\
are consistent with Opuntia spp. (prickly pear) \\
Chenopodiaceae (goosefoot) and \\
Amaranthaceae (pigweed) families \\
Chloridoid & Poaceae (grass family) chloridoid subgroup. \\
Festucoid & Poaceae (grass family) festudoid subgroup \\
Panicoid & Poaceae (grass family) panicoid subgroup \\
Other grass & Poaceae (grass Family) type undefined \\
Fabaceae & Bean family \\
Cucurbita pepo & Cultivated squash \\
C. foetidissima & Wild gourd \\
Phaseolus vulgaris & Cultivated bean
\end{tabular}

For Bighorn Cave, Cactaceae and Agavaceae were ubiquitous (Table 2). Silica phytoliths from wild legumes and Cheno/Ams were also found. Previous analysis [20] revealed that wild legumes were eaten at this site in the form of pods from mesquite (Prosopis). Thus, mesquite pods could have been a source of microscopic abrasives. Silica grass phytoliths were found in small numbers in a few coprolites. These coprolites also contained rodent remains.

Calcium oxalate phytoliths are ubiquitous in coprolites from Dust Devil Cave (Table 3). Cactaceae and/or Agavaceae phytoliths are present in every coprolite. Reinhard [16] identified the source of the Agavaceae phytoliths as from yucca (Yucca). We also found silica phytoliths in the coprolites from the bean family, the grass family, and the Chenopodiaceae or Amaranthaceae families. Chenopodium seed and grass seed from the genus Sporobolus (dropseed) were commonly eaten at the site [19]. However, until the phytolith analysis was completed, it was not known that the greens of Cheno/ Ams were eaten. Thus, the phytolith analysis added new perspectives on wild plant use. Rabbit bones and/or hair were found in 58 of 100 coprolites analyzed for macroscopic remains [17].

Ancestral Pueblo coprolites also contain phytoliths. However, it is important to note that phytoliths do not make up the high volume of fecal residue as commonly seen in Archaic coprolites. For Ancestral Pueblo coprolites, phytoliths make up less then $5 \%$ of the fecal volume. One of the main foods at all Ancestral Pueblo sites was maize. However, maize kernels and foods made from maize kernels, are not high in phytoliths. Distinctive maize phytoliths are found in the leaves, not the kernels.

The coprolites from the Ancestral Pueblo Site, Bighorn Sheep Ruin, contained calcium oxalate and silica phytoliths (Table 4). All coprolites from this site contained abundant phytoliths and 200 phytolith counts were achieved for all coprolites. Identifiable phytoliths were present in 19 coprolites. One coprolite contained phytoliths of an unknown plant. Calcium oxalate phytoliths from Agavaceae were found in 12 of 20 coprolites. Calcium oxalate phytoliths from Cactaceae were found in 10 of 20 coprolites. Fourteen coprolites contained calcium oxalate crystals from one or the other, or both of these families. Silica phytoliths were present in all coprolites and were more abundant than calcium oxalate phytoliths in 18 coprolites. Silica phytoliths were from the Chenopodiaceae, Amaranthaceae, Poaceae, Fabaceae, and Cucurbitaceae. These include cultivated squash, Cucurbita pepo, and cultivated bean, Phaseolus vulgaris.

All coprolites from Antelope House contained abundant phytoliths and 23 of 25 coprolites contained calcium oxalate phytoliths (Table 5). For all coprolites from this site, 200 phytolith counts were achieved. Phytoliths of 
Table 2

Phytolith percentages from Bighorn Cave, Arizona in the Mojave Desert $(n=17)$

\begin{tabular}{|c|c|c|c|c|c|c|c|c|c|c|c|c|c|c|c|c|c|}
\hline Coprolites & 1 & 2 & 3 & 4 & 5 & 6 & 7 & 8 & 9 & 10 & 11 & 12 & 13 & 14 & 15 & 16 & 17 \\
\hline Agavaceae & 55 & 68.5 & 77.5 & 1 & 0 & 25 & 0.9 & 43 & 15 & 50 & 98 & 88 & 6 & 6 & 2.8 & 22 & 34 \\
\hline Cactaceae & 14 & 0.3 & 4 & 50 & 60 & 26.5 & 1 & 0 & 6 & 0 & 2 & 0 & 28 & 30 & 43 & 51 & 44 \\
\hline Cheno/Am & 6 & 0.7 & 0 & 4 & 37 & 34 & 5 & 0 & 1 & 0 & 0 & 0.5 & 29 & 9 & 34 & 23 & 20 \\
\hline Chloridoid & 0 & 0 & 0.7 & 0 & 0 & 0 & 0 & 2 & 0.4 & 0 & 0 & 1 & 0 & 0 & 0 & 0 & 0 \\
\hline Festucoid & 0 & 5 & 2 & 2 & 0 & 2 & 0 & 10 & 5 & 50 & 0 & 4 & 0.4 & 2 & 3 & 3 & 0.4 \\
\hline Panicoid & 0 & 0.3 & 0.7 & 0.9 & 0 & 0.8 & 0 & 0.4 & 0.8 & 0 & 0 & 6 & 0 & 0.7 & 12 & 0.4 & 1 \\
\hline Other grass & 0 & 0 & 0 & 0 & 0 & 0 & 0 & 0.7 & 0 & 0 & 0 & 0 & 0 & 0 & 0 & 0 & 0 \\
\hline Fabaceae & 25 & 25 & 15 & 42 & 3 & 12 & 93 & 43 & 69 & 0 & 0 & 0 & 36 & 52 & 5 & 0 & 0 \\
\hline Cucurbita & 0 & 0 & 0 & 0 & 0 & 0 & 0 & 0 & 1 & 0 & 0 & 0 & 0 & 0 & 0 & 0 & 0 \\
\hline Total count & 275 & 288 & 281 & 224 & 229 & 240 & 226 & 268 & 225 & 10 & 49 & 209 & 238 & 286 & 264 & 225 & 280 \\
\hline
\end{tabular}

The numbers are percentage expressions of the total count for each coprolite. The total phytoliths counted are also presented. The Cucurbita phytoliths are consistent with the species Cucurbita foetidissima.

Agavaceae and Cactaceae were nearly ubiquitous in these coprolites. However, silica phytoliths were more abundant in Antelope House coprolites. Calcium oxalate phytoliths dominated in only nine coprolites. Silica phytoliths were present in 22 coprolites from the same plant families as those for Bighorn Sheep Ruin.

Phytoliths were rare in Salmon Ruin coprolites (Table 6). Only seven of 20 coprolites contained sufficient phytoliths to make 200 phytolith counts. Of these seven, all phytolith counts were dominated by calcium oxalate phytoliths of the Agavaceae and Cactaceae. Silica phytoliths were encountered from the Chenopodiaceae, Amaranthaceae, Poaceae, Fabaceae, and Cucurbitaceae families.

\section{Discussion}

Coprolite analysis shows that prehistoric people often ate small animals. Reinhard et al. [20] found that grass phytoliths were found in coprolites that also contained rodent remains at Bighorn Cave. They concluded that the grass phytoliths were introduced into the human digestive tract when small animals were eaten whole. This is an important consideration because small animal bone occurs in all Archaic and Ancestral Pueblo sites presented here [17]. Therefore, we suspect that trace amounts of grass phytoliths may be evidence of meat consumption, not plant consumption.

The additional analyses of phytolith content from hunter-gatherer coprolites support our previous prediction that calcium oxalate phytolith-rich plants were Archaic hunter-gatherer dietary staples [5]. The analyses also support Reinhard's [17] reconstruction of the nucleus of Archaic diet which included species of the genera Agave, Yucca, and Opuntia. In our previous work, we were able to definitively link the consumption of Agavaceae and Cactaceae food sources with dental wear in the Chihuahua Desert of Texas [5]. The additional analyses presented here indicate that the same plants were the basis of desert diets in other xeric regions and probably caused dental microwear among Sonoran Desert and Colorado Plateau hunter-gatherers.

Preparation and consumption of desert succulents, especially in the agave family, produces dental wear. These plants are especially rich in course fibers, phytoliths, and toxins. To render the plants edible, they must be pried from the ground, the outer leaves must be cut away, and the basal portion of the plants (called hearts) must be roasted in pit ovens for up to 2 days. The hearts are then eaten. However, even after this preparation, the hearts are still rich in fiber and phytoliths. To eat the hearts, sections are chewed until the digestible carbohydrate is released. Then the fibrous portion is spit out. The expelled fibers are called quids.

Table 3

Phytolith percentages from Dust Devil Cave, Utah in the Colorado Plateau ecological region $(n=17)$

\begin{tabular}{|c|c|c|c|c|c|c|c|c|c|c|c|c|c|c|c|c|c|}
\hline Coprolites & 1 & 2 & 3 & 4 & 5 & 6 & 7 & 8 & 9 & 10 & 11 & 12 & 13 & 14 & 15 & 16 & 17 \\
\hline Agavaceae & 98 & 15 & 20 & 2 & 86 & 84 & 25 & 33 & 33 & 5 & 97 & 88 & 99 & 99 & 1 & 73 & 0 \\
\hline Cactaceae & 0 & 45 & 59 & 60 & 11 & 0 & 0 & 20 & 0 & 91 & 0 & 8 & 0 & 0 & 29 & 0.4 & 33 \\
\hline Cheno/Am & 2 & 40 & 21 & 38 & 3 & 0 & 0 & 47 & 0 & 4 & 0 & 4 & 0 & 0 & 70 & 16 & 67 \\
\hline Chloridoid & 0 & 0 & 0 & 0 & 0 & 3 & 0 & 0 & 0 & 0 & 0 & 0 & 0 & 0 & 0 & 0 & 0 \\
\hline Festucoid & 0 & 0 & 0 & 0 & 0 & 0 & 2 & 0 & 33 & 0 & 2 & 0 & 0.5 & 0 & 0 & 0 & 0 \\
\hline Panicoid & 0 & 0 & 0 & 0 & 0 & 12 & 73 & 0 & 17 & 0 & 0.5 & 0 & 0 & 0.5 & 0 & 0.4 & 0 \\
\hline Fabaceae & 0 & 0 & 0 & 0 & 0 & 0 & 0 & 0 & 17 & 0 & 0.5 & 0 & 0 & 0 & 0 & 10 & 0 \\
\hline Total count & 200 & 203 & 208 & 210 & 348 & 203 & 233 & 236 & 12 & 224 & 206 & 273 & 210 & 200 & 224 & 238 & 3 \\
\hline
\end{tabular}

The numbers are percentage expressions of the total count for each coprolite. The total phytoliths counted are also presented. 
Table 4

Phytolith percentages from Bighorn Sheep Ruin, Utah $(n=20)$

\begin{tabular}{|c|c|c|c|c|c|c|c|c|c|c|c|c|c|c|c|c|c|c|c|c|}
\hline Coprolites & 1 & 2 & 3 & 4 & 5 & 6 & 7 & 8 & 9 & 10 & 11 & 12 & 13 & 14 & 15 & 16 & 17 & 18 & 19 & 20 \\
\hline Agavaceae & 0 & 0.8 & 0 & 8 & 78 & 0.4 & 3 & 0 & 0 & 35 & 93 & 12 & 4 & 0 & 0 & 0 & 3 & 0 & 0.4 & 33 \\
\hline Cactaceae & 0 & 0 & 1 & 0 & 6 & 30 & 0 & 0 & 0 & 3 & 0.4 & 1 & 0 & 10 & 0 & 0 & 2 & 0 & 42 & 19 \\
\hline Cheno/Am & 0 & 0 & 29 & 0.6 & 15 & 68 & 0 & 0 & 0 & 20 & 0 & 0 & 0 & 2 & 0 & 0 & 0 & 0 & 57 & 48 \\
\hline Chloridoid & 3 & 6 & 1 & 3 & 0 & 0 & 0 & 0 & 0 & 0 & 0 & 0.6 & 15 & 4 & 0.5 & 10 & 5 & 0 & 0 & 0 \\
\hline Festucoid & 37 & 30 & 29 & 39 & 0 & 1 & 3 & 0 & 0 & 10 & 0.4 & 18 & 41 & 20 & 7 & 14 & 55 & 5 & 0 & 0 \\
\hline Panicoid & 50 & 26 & 1 & 6 & 0 & 0.4 & 2 & 0.5 & 0 & 29 & 0 & 2 & 31 & 60 & 89 & 75 & 22 & 51 & 0 & 0 \\
\hline Other grass & 1 & 0.8 & 0 & 0 & 0 & 0 & 0 & 0 & 0 & 0 & 0 & 0.6 & 1 & 0 & 0.5 & 0 & 1 & 0 & 0 & 0 \\
\hline Fabaceae & 9 & 36 & 39 & 43 & 0 & 0 & 84 & 0 & 0 & 2 & 6 & 65 & 8 & 4 & 3 & 0 & 11 & 44 & 0 & 0 \\
\hline C. реро & 0 & 0 & 0 & 0 & 0 & 0 & 0.5 & 0 & 0 & 0 & 0 & 0 & 0 & 0 & 0 & 0 & 0 & 0 & 0 & 0 \\
\hline P. vulgaris & 0 & 0 & 0 & 0 & 0 & 0 & 7 & 0 & 0 & 0 & 0 & 0 & 0 & 0 & 0 & 0 & 0 & 0 & 0 & 0 \\
\hline Unidentifiable & 0 & 0 & 0 & 0 & 0 & 0 & 0 & 99.5 & 0 & 0 & 0 & 0 & 0 & 0 & 0 & 0 & 0 & 0 & 0 & 0 \\
\hline
\end{tabular}

The numbers are percentage expressions of the total count for each coprolite. The total phytoliths counted are also presented.

Because the quid fibers are associated with dense clusters of wedge-shape phytoliths, it is the mastication of the quids that caused dental wear.

In examination of coprolite microfossils from Hinds Cave, Dust Devil Cave, and Bighorn Cave, phytoliths of the Agavaceae family were found free of other plant material as well as imbedded in fiber bundles. This indicates that mastication of plant tissue liberated the phytoliths and therefore the phytoliths were in direct contact with the dentition during mastication. In contrast, cactus phytoliths were often observed within the cell walls of cactus epidermis tissue and less often observed free in the matrix of coprolites. In extraction of phytoliths from cactus pads, we found that most of the phytoliths are inside epidermal cells and relatively few are in the soft tissue within the pad of the cactus. Therefore, we believe that phytoliths from plants in the Agavaceae (Agave and Yucca) were a more common cause of dental microwear than cactus.

The analysis of the three Ancestral Pueblo sites indicates that agricultural foods did not completely replace non-domesticated foods in the horticultural diet. Indeed, Reinhard [17] and Sutton and Reinhard [28] discovered that the diversity of wild plants eaten by Ancestral Pueblo horticulturalists was actually greater than hunter-gatherers. At two Ancestral Pueblo sites, calcium oxalate crystals from Agavaceae and Cactaceae were common or nearly ubiquitous. In addition, silica phytoliths were more abundant in horticultural coprolites. Only at Salmon Ruin were phytoliths relatively rare in coprolites.

Other analyses show that maize was more commonly eaten at Salmon Ruin than Antelope House. The dietary analyses of Antelope House and Salmon Ruin are of interest [18,17,28]. The macroscopic analysis of 180 Antelope House coprolites showed that maize was commonly eaten except in period of food shortage at Antelope House [28]. However, this analysis was based on presence/absence data from macroscopic analysis of coprolites and presents an exaggerated estimation of maize consumption at Antelope House. During periods of food shortage, yucca and cactus were eaten [28].

Palynological comparison of the sites presented a different dietary picture [21]. The background pollen indicated similar seasonal use of both sites. The Salmon Ruin Ancestral Pueblo ate more maize, and especially ground maize (as represented by torn maize pollen), than Antelope House. At Antelope House, there was a reliance on pollen and spore producing wild plants such as cattail and horsetail. Other foods, spices, or medicines were represented in the pollen spectra from both sites including Cleome (beeweed), Amaranthaceae/

Table 5

Phytolith percentages from Antelope House, Arizona $(n=25)$

\begin{tabular}{lrrrrrrrrrrrrrrrrrrrrrrrrrrrrrrrrrrrr}
\hline Coprolites & 1 & 2 & 3 & 4 & 5 & 6 & \multicolumn{1}{c}{7} & 8 & 9 & 10 & 11 & 12 & 13 & 14 & 15 & 16 & 17 & 18 & 19 & 20 & 21 & 22 & 23 & 24 & 25 \\
\hline Agavaceae & 0 & 1 & 57 & 57 & 1 & 0 & 2.5 & 0 & 69 & 0 & 0 & 0 & 18 & 58 & 4 & 0 & 12 & 8 & 9 & 65 & 55 & 4 & 3 & 71 & 0.5 \\
Cactaceae & 0 & 14 & 0 & 30 & 91 & 92 & 0 & 0.5 & 8 & 28 & 47 & 0 & 5 & 42 & 0 & 33 & 86 & 18 & 7 & 20 & 10 & 18 & 37 & 7 & 18 \\
Cheno/Am & 0 & 0 & 24 & 8 & 0 & 0 & 0 & 0 & 16 & 0 & 42 & 0 & 6 & 0 & 16 & 0 & 0 & 71 & 0 & 4 & 32 & 24 & 54 & 5 & 75 \\
Chloridoid & 0 & 1 & 0 & 0 & 0 & 0 & 0 & 0 & 0 & 0 & 0 & 0 & 0 & 0 & 0 & 0 & 0 & 0 & 0 & 1 & 0 & 0 & 0 & 0 & 0 \\
Festucoid & 0 & 0 & 0 & 0 & 0 & 0 & 0 & 0 & 0 & 0 & 0 & 0 & 0 & 0 & 0 & 0 & 0 & 0 & 0 & 1 & 0 & 0 & 0 & 0 & 0 \\
Panicoid & 0 & 0 & 3 & 0 & 0 & 0 & 0 & 0 & 1 & 0 & 0 & 0 & 0 & 0 & 9 & 0 & 0 & 1 & 0 & 1 & 3 & 1 & 0 & 0 & 1 \\
Other grass & 0 & 1 & 0 & 0 & 0 & 0 & 0 & 0 & 0 & 0 & 0 & 0 & 0 & 0 & 1 & 0 & 0 & 0 & 0 & 0 & 0 & 0 & 0 & 0 & 0 \\
Fabaceae & 0 & 76 & 15 & 5 & 8 & 8 & 0.5 & 2 & 6 & 64 & 11 & 0 & 68 & 0 & 69 & 67 & 1 & 2 & 0 & 8 & 0 & 36 & 6 & 14 & 5 \\
P. vulgaris & 0 & 7 & 0 & 0 & 0 & 0 & 0 & 0 & 0 & 8 & 0 & 1 & 3 & 0 & 0 & 0 & 0 & 0 & 0 & 0 & 0 & 17 & 0 & 3 & 0 \\
Unidentifiable & 0 & 0 & 0 & 0 & 0 & 0 & 97 & 97.5 & 0 & 0 & 0 & 99.5 & 0 & 0 & 0 & 0 & 0 & 0 & 84 & 0 & 0 & 0 & 0 & 0 & 0
\end{tabular}

The numbers are percentage expressions of the total count for each coprolite. The total phytoliths counted are also presented. 
Table 6

Phytolith percentages from Salmon Ruin, New Mexico $(n=20)$

\begin{tabular}{lrrrrrrrrrrrrrrrrrrrrrrrrrrrrrrrrrrr}
\hline Coprolites & 1 & 2 & 3 & 4 & 5 & 6 & 7 & 8 & 9 & 10 & 11 & 12 & 13 & 14 & 15 & 16 & 17 & 18 & 19 & 20 \\
\hline Agavaceae & 0 & 0 & 0 & 0 & 0.5 & 0 & 0 & 0 & 34 & 0 & 4 & 86 & 81 & 47 & 88 & 85 & 95 & 9 & 0 & 0 \\
Cactaceae & 0 & 0 & 0 & 0 & 0 & 0 & 0 & 0 & 46 & 0 & 52 & 0 & 13 & 13 & 2 & 1 & 2 & 83 & 4 & 0 \\
Cheno/Am & 0 & 0 & 0 & 0 & 0 & 0 & 0 & 0 & 20 & 0 & 44 & 0 & 5 & 38 & 2 & 5 & 3 & 8 & 51 & 0 \\
Festucoid & 0 & 0 & 47 & 0 & 0.5 & 0 & 0 & 0 & 0 & 0 & 0 & 5 & 0.4 & 0.5 & 8 & 4 & 0 & 0 & 41 & 0 \\
Panicoid & 100 & 0 & 0 & 0 & 0 & 0 & 0 & 0 & 0 & 0 & 0 & 9 & 0 & 0 & 0 & 0 & 0 & 0 & 2 & 0 \\
Other grass & 0 & 0 & 0 & 0 & 0 & 0 & 0 & 0 & 0 & 0 & 0 & 0 & 0 & 0.5 & 0 & 0 & 0 & 0 & 0 & 0 \\
Fabaceae & 0 & 0 & 53 & 0 & 0 & 0 & 0 & 0 & 0 & 0 & 0 & 0 & 0 & 0.5 & 0 & 5 & 0 & 0 & 1 & 0 \\
C. pepo & 0 & 0 & 0 & 0 & 0 & 0 & 0 & 0 & 0 & 0 & 0 & 0 & 0 & 0 & 0 & 0.5 & 0 & 0 & 0 & 0 \\
Unidentifiable & 0 & 0 & 0 & 0 & 99 & 0 & 0 & 0 & 0 & 0 & 0 & 0 & 0 & 0 & 0 & 0 & 0 & 0 & 0 & 0 \\
Total count & 1 & 0 & 17 & 0 & 2 & 0 & 0 & 0 & 215 & 0 & 273 & 55 & 228 & 207 & 179 & 221 & 239 & 208 & 74 & 0 \\
\hline
\end{tabular}

The numbers are percentage expressions of the total count for each coprolite. The total phytoliths counted are also presented.

Chenopodiaceae (pigweed and goosefoot families), Platyopuntia (prickly pear), and two types of Asteraceae (sunflower family).

Unpublished, on-going starch analysis is also insightful. Of 20 Salmon Ruin coprolites analyzed, 19 contain maize starch granules (Reinhard, current research). Of 20 Antelope House coprolites analyzed, only nine contain maize starch granules. Therefore, microscopic analysis shows that these sites did not have an equivalent diet and that Antelope House inhabitants depended more on wild plants in all seasons than did Salmon Ruin inhabitants [21]. Reinhard et al. [21] conclude that the Pueblo III occupation of Antelope House had a diversified subsistence strategy, perhaps resulting from horticulture failure.

This analysis shows that phytolith dietary abrasives were part of the normal Archaic diet in the deserts of North America. It also shows that wild plant foods rich in phytoliths continued to be commonly eaten in horticultural times. However, horticulture on the Colorado Plateau was never completely dependent on cultivated plant foods such as maize kernels that were low in phytolith content.

The difference in phytolith content between sites leads us to hypothesize that differences in dental disease should be seen in dental analysis. We first hypothesize that dental wear would be greater in hunter-gatherers than horticulturalists. Analyses of dental pathology have been published for the southwestern Archaic and Ancestral Pueblo cultures. Schmucker [25] compares Archaic California hunter-gatherer dental pathology with that of one historic Pueblo site, Gran Quivira. She finds that dental attrition is more common among the hunter-gatherer skeletons and caries levels are higher for the Ancestral Pueblo. However, Gran Quivira was occupied well into historic times and may not represent Ancestral Pueblo subsistence.

Since differences are evident between Ancestral Pueblo sites, we hypothesize that dental pathology should vary between sites like Antelope House which had a higher reliance on phytolith-rich foods and
Salmon Ruin which had lower reliance on such foods. Berry [3], El-Najjar [6], and Stodder and Martin [27] present general surveys of dental pathology for Ancestral Pueblo sites. They include in their analyses comparison of caries and abscess frequencies. Berry compares the dental pathology of five Ancestral Pueblo sites and two Mogollon sites. He finds that the prevalence of caries, abscesses, and antemortem tooth loss is lower for Salmon Ruin. We hypothesize that the lower amounts of phytoliths in Salmon Ruin diet contributed to better dental health at this site. El-Najjar [6] presents a comparative evaluation of Antelope House relative to other Ancestral Pueblo sites. He finds that dental wear is higher for Antelope House but dental caries is lower.

Stodder and Martin compare prevalence of caries and abscess among 15 pueblo sites. This study is more extensive and better controlled than Berry's [3] or ElNajjar's [6]. Their caries data are from 19 occupations of these sites. The caries rate ranges from $9 \%$ to $85 \%$. Salmon Ruin, at $20 \%$, has one of the lowest caries rates and only three occupations have lower rates. Stodder and Martin report abscess rates for 17 occupations ranging from $11 \%$ to $66 \%$. Salmon Ruin has a moderate abscess prevalence of $35 \%$.

From the coprolite phytolith data, we can hypothesize an explanation for some Ancestral Puebloan dental pathology variation. The coprolites and skeletons from Antelope House in Canyon de Chelly date to a time of ecological collapse [16]. The coprolites and skeletons from Salmon Ruin date to a time of ecological stability and agricultural productivity. Previous analyses of coprolites show that starvation foods are abundant in Antelope House coprolites and nearly absent in Salmon Ruin coprolites [17,21]. Starvation foods include yucca and prickly pear cactus, both of which are high in calcium oxalate phytoliths. As noted in the results sections, phytoliths were abundant in Antelope House coprolites but rarer in Salmon Ruin coprolites. The increased reliance on phytolith-rich plants at Antelope House clearly explains the high rate of wear at that site, 
especially in context of previous research that shows a relation between calcium oxalate phytoliths in coprolites and dental microwear for western Texas [5].

The dental problems caused by consumption of Agavaceae and Cactaceae food plants was a problem for Salado and Hohokam in the southern deserts of Arizona as well as xeric-adapted peoples in Mexico $[4,23,26]$. Agave was cultivated by the Hohokam in the Sonoran Desert, just as it was in central Mexico [7,8]. Therefore, the impact of Agave on dentition probably paralleled that of central Mexico. The use of Agave in northern Mesoamerica was established from the Tehuacan excavations. Both hunter-gatherers and agriculturalists subsisted on Agave and cactus [4,26]. The Tehuacan researchers made a connection between desert succulent diet and dental disease $[1,4,26]$. Excavations in the Tehuacan Valley of southern Mexico unearthed 10,000 Agave (maguey) quids from five caves. Seventy skeletons were also excavated. Tehuacan dentition showed marked dental attrition and tooth loss, which was attributed to "the course, abrasive diet of people who gathered a large part of their food from the natural vegetation, among which maguey and various cactus are present" [1:106]. The attrition was noted in children as young as 8 years old as well as adults. The analysis of quids [26] and coprolites [4] showed an unbroken record of Agave subsistence for the Tehuacan Valley.

Southwestern archaeology has reached a stage at which botanical analyses can be used to establish hypotheses that can be tested by paleopathological data. Understanding the relationship between diet, phytoliths, microwear and dental health is an important contribution to the study of diet and health in the Southwest. Phytolith study from coprolites provides a line of evidence that can be used to hypothesize ecological and temporal differences in subsistence patterns. Such hypotheses can only be tested by dental analysis. However, in order to document this relationship, paleopathologists must take care in reporting their data. One of the most important points is that paleopathologists need to keep in mind the relationship of age to dental pathology. Berry's dissertation [2:60] states that the skeletal assemblage from Salmon Ruin is underrepresentative of adults. Of the 65 individuals he reports from Salmon Ruin, only 20 are between the ages of 14 and 45, the peak age of caries formation in Anasazi. Caries and other categories of dental pathology are explicitly age-related, so one could argue that the apparently better dental health status of the Salmon Ruin population is an artifact of the peculiar age distribution of this assemblage, not of dietary differences. Controlling sample ages is very important in analysis of Ancestral Pueblo sites. This is because Ancestral Puebloans had fundamentally similar diets and thus researchers must look for very specific, localized differences. Therefore, attention to detail is necessary.
We conclude that dental wear caused by desert succulent plant consumption was common in all three arid areas studied: the Coahuiltecan Desert of Texas, the Sonoran Desert of Arizona, and the Colorado Plateau of Utah. Although Ancestral Puebloan villages generally decreased their reliance on desert succulents, they still relied on Yucca and cactus during periods of low horticultural productivity. Therefore, at certain Pueblos at certain times, the threat of dental wear increased as villagers exploited available desert plants to avoid famine.

\section{Acknowledgements}

We thank Nancy Akins and anonymous JAS reviewers for helpful comments that substantially improved the presentation and interpretation of the data.

\section{References}

[1] J.E. Anderson, The human skeletons, in: D.S. Byers (Ed.), Environment and Subsistence, The prehistory of the Tehuacan Valley, vol. 1, University of Texas Press, Austin, 1967, pp. 91-113.

[2] D.R. Berry, Disease and climatological relationships among Pueblo III-Pueblo IV Ancestral Pueblo of the Colorado Plateau, PhD dissertation, University of California, Los Angeles, 1983.

[3] D.R. Berry, Dental paleopathology of Grasshopper Pueblo, in: R.J. Miller, C.F. Merbs (Eds.), Health and Disease in the Prehistoric Southwest, Arizona State University Anthropological Research Papers 34, Arizona State University, Tempe, 1985, pp. 253-274.

[4] E.O. Callen, Analysis of Tehuacan coprolites, in: D.S. Byers (Ed.), Environment and Subsistence, The prehistory of the Tehuacan Valley, vol. 1, University of Texas Press, Austin, 1967, pp. 261-289.

[5] D.R. Danielson, K.J. Reinhard, Human dental microwear caused by calcium oxalate phytoliths in prehistoric diet of the lower Pecos region, Texas, Am. J. Phys. Anthropol. 107 (1998) 297-304.

[6] M.Y. El-Naijar, The biology and health of the prehistoric inhabitants of Canyon de Chelly, in: D.P. Morris (Ed.), Archaeological Investigations at Antelope House, US Government Printing Office, Washington, DC, 1986, pp. 206-220.

[7] S.K. Fish, P.R. Fish, C. Miksicek, J. Madsen, Prehistoric Agave cultivation in Southern Arizona, Desert Plants 7 (1985) 107-112.

[8] S.K. Fish, J. Madsen, Evidence for large-scale Agave cultivation in the Marana Community, in: S.K. Fish, P.R. Fish, J. Madsen (Eds.), The Marana Community in the Hohokam World, Anthropological Papers of the University of Arizona Number 56, University of Arizona Press, Tucson, 1992, pp. 73-87.

[9] G.F. Fry, Prehistoric diet and parasites in the desert west of North America, in: D. Bowman (Ed.), Early Native Americans, Mouton Press, The Hague, 1980, pp. 325-329.

[10] I.L. Gügel, G. Grupe, K. Kunzelmann, Simulation of dental microwear: characteristic traces by opal phytoliths give clues to ancient dietary behavior, Am. J. Phys. Anthropol. 114 (2001) $124-138$.

[11] B. Holt, Phytoliths from dental calculus: direct evidence of prehistoric diet, Phytolitharien Newsl. 7 (1993) 8. 
[12] C. Lalueza Fox, J. Juan, R.M. Albert, Phytolith analysis on dental calculus, enamel surface, and burial soil: information about diet and palaeoenvironment, Am. J. Phys. Anthropol. 101 (1996) $101-113$.

[13] C. Lalueza Fox, A. Pérez-Pérez, Dietary information through the examination of plant phytoliths on the enamel surface of human dentition, J. Archaeol. Sci. 21 (1994) 29-34.

[14] W. Middleton, The identification of pre-Hispanic coca consumption through opal phytoliths analysis of dental calculus, Phytolitharien Newsl. 7 (1993) 8.

[15] P.E. Minnis, Prehistoric diet in the northern Southwest: macroplant remains from Four Corners feces, Am. Antiq. 54 (1989) $543-563$.

[16] K.J. Reinhard, Cultural ecology of parasitism, MS thesis, Northern Arizona University, Flagstaff, 1985.

[17] K.J. Reinhard, Patterns of diet, parasitism, and anemia in prehistoric west North America, in: P. Stuart-Macadam, S. Kent (Eds.), Diet, Demography, and Disease: Changing Perspectives on Anemia, Aldine de Gruyter Press, New York, 1992, pp. 219-258.

[18] K.J. Reinhard, Parasite ecology of two Ancestral Pueblo villages, in: E.J. Reitz, L.A. Newson, S.J. Scudder (Eds.), Case Studies in Environmental Archaeology, Plenum Press, New York, 1996, pp. $245-288$.

[19] K.J. Reinhard, J.R. Ambler, M. McGuffie, Diet and parasitism at Dust Devil Cave, Am. Antiq. 50 (1985) 819-824.

[20] K.J. Reinhard, M. Daniels, D.R. Danielson, S. Miranda Chaves, Multidisciplinary coprolite analysis, in: P.R. Geib, D.R. Keller (Eds.), Bighorn Cave: Test Excavation of a Stratified Dry Shelter, Mojave County, Arizona, Bilby Research Center Occasional Papers 1, Northern Arizona University, Flagstaff, 2002, pp. $135-152$.
[21] K.J. Reinhard, D.K. Meier, S.K. Edwards, T. Damon, Pollen concentration analysis in documenting Anasazi dietary variation, J. Palaeogeogr. Palaeoclimatol. Palaeoecol. in press.

[22] K.J. Reinhard, S.M.F. Souza, C.D. Rodrigues, E. Kimmerle, S. Dorsey-Vinton, Microfossils in dental calculus: a new perspective on diet and dental disease, in: E. Williams (Ed.), Human Remains: Conservation, Retrieval, and Analysis, British Archaeology Research Council, London, 2001, pp. 113-118.

[23] J.R.K. Robson, J.N. Elias, Nutritional significance of the Guilá Naquitz food remains, in: K. Flannery (Ed.), Guilá Naquitz: Archaic Foraging and Early Agriculture on Oaxaca, Mexico, Academic Press, New York, 1986, pp. 297-301.

[24] C.W. Schmidt, Dental microwear evidence for a dietary shift between two nonmaize-reliant prehistoric human populations from Indiana, Am. J. Phys. Anthropol. 114 (2001) 139-145.

[25] B.J. Schmucker, Dental attrition: a correlative study of dietary and subsistence patterns, in: R.J. Miller, C.F. Merbs (Eds.), Health and Disease in the Prehistoric Southwest, Arizona State University Anthropological Research Papers 34, Arizona State University, Tempe, 1985 , pp. 275-322.

[26] C.E. Smith, Plant reomains, in: D.S. Byers (Ed.), Environment and Subsistence, The prehistory of the Tehuacan Valley, vol. 1, University of Texas Press, Austin, 1967, pp. 220-255.

[27] A.L.W. Stodder, D.L. Martin, Health and disease in the southwest before and after contact, in: J.W. Verano, D.H. Ubelaker (Eds.), Disease and Demography in the Americas, Smithsonian Institution Press, Washington, DC, 1992, pp. 55-73.

[28] M.Q. Sutton, K.J. Reinhard, Cluster analysis of the coprolites from Antelope House: implications for Ancestral Pueblo diet and cuisine, J. Archaeol. Sci. 22 (1995) 741-750.

[29] P.S. Ungar, A semiautimated image analysis procedure for the quantification of dental microwear II, Scanning 17 (1995) 57-59. 